ROCZNIKI HUMANISTYCZNE

Tom LXVIII, zeszyt $2-2020$

DOI: http://dx.doi.org/10.18290/rh20682-6

DOROTA WEREDA

\title{
KASATA KLASZTORU BAZYLIANÓW W BIAŁEJ PODLASKIEJ
}

Zakon bazylianów (Ordo Sancti Basilii Magni - OSBM) powstał w wyniku przeprowadzonej na początku XVII wieku przez Józefa Welamina Rutskiego reformy kilku monasterów prawosławnych, które przystąpiły do unii brzeskiej (1596 r.). W 1617 r. powołano Kongregację Trójcy Świętej (zwaną też Zakonem Świętego Bazylego Wielkiego), złożoną z pięciu monasterów (Wilno, Byteń, Mińsk, Nowogrodek, Żyrowice) położonych na terenie Wielkiego Księstwa Litewskiego, które zaakceptowały unię z Kościołem łacińskim. Dzięki nowym fundacjom, głównie magnackim, w XVII i XVIII stuleciu powstawały kolejne placówki. W drugiej połowie XVIII wieku na rozległych i odległych od szlaków komunikacyjnych obszarach wiejskich ziem litewsko-ruskich i koronnych działało 140 monasterów. Działalność duszpasterska, oświatowo-wychowawcza, charytatywna (przytułki, szpitale, apteki), edytorska i typograficzna zgromadzenia bazylianów stała się fundamentalnym czynnikiem formowania Cerkwi unickiej metropolii kijowskiej.

Bazyliański klasztor w Białej Podlaskiej ${ }^{1}$ był fundacją magnacką. Inicjatorką jego utworzenia była Katarzyna z Sobieskich Radziwiłłowa, siostra króla Jana III Sobieskiego. Celem fundacji, zatwierdzonej przez sejm w 1690 r., była animacja postaw religijnych poddanych obrządku greckiego zamieszkujących bialskie dobra Radziwiłłów oraz podniesienie poziomu wiedzy religijnej ${ }^{2}$.

Dr hab. Dorota Wereda, prof. UPH - Uniwersytet Przyrodniczo-Humanistyczny w Siedlcach, Wydział Humanistyczny, Instytut Historii i Stosunków Międzynarodowych; adres do koresponencji — e-mail: dorota.wereda@uph.edu.pl; ORCID: https://orcid.org/0000-0003-1084-2212.

${ }^{1}$ Miasto noszące pierwotnie nazwę Biała Radziwiłłowska zaczęto nazywać Białą Podlaską po utworzeniu w 1837 r. guberni podlaskiej. S. WARCHOE, Nazwy miast Lubelszczyzny, Lublin 1964, s. 13.

${ }^{2}$ Volumina Legum, t. V, s. 401; L. BIEŃKOwsKi, Organizacja Kościoła wschodniego w Polsce, w: Kościót w Polsce, t. II: Wiek XVI-XVIII, red. J. Kłoczowski, Kraków 1968, s. 1013. 
Bialski ośrodek dzięki bliskości książęcej siedziby szybko uzyskał znaczącą pozycję w strukturze zgromadzenia. Do podniesienia rangi bialskiej placówki bazylianów przyczyniła się obecność od początku XVIII stulecia na książęcym zamku Radziwiłłów w Białej relikwii męczennika za unię bł. (wówczas) Jozafata Kuncewicza. Placówka bazylianów w Białej prowadziła działalność duszpasterską, misyjną i promującą kult bł. Jozafata. Po 1815 r. bazyliański klasztor w Białej należał do Prowincji Księży Bazylianów pod opieką Narodzenia Najświętszej Panny Marii w Królestwie Polskim (wraz z klasztorami w Chełmie, Lublinie, Warszawie, Zamościu).

Celem artykułu jest analiza realizacji ukazu kasacyjnego wydanego przez cara 28 listopada (10 grudnia) 1864 r. Proces kasaty poddany zostanie analizie zarówno w aspekcie organizacyjnym, odtworzenia losów spuścizny materialnej i księgozbioru, jak też wpływu tej decyzji na funkcjonowanie lokalnej społeczności. Likwidacja bazyliańskiego ośrodka w Białej zostanie przedstawiona również w kontekście polityki rusyfikacji. Analiza realizacji ukazu kasacyjnego w bialskim klasztorze bazylianów stanowi uzupełnienie dotychczasowej wiedzy na temat kasaty zgromadzenia bazylianów w Królestwie Polskim oraz o polityce rosyjskiej wobec ludności ziem polskich w XIX wieku.

Dokumenty podpisane przez cara Aleksandra II 27 października (według kalendarza gregoriańskiego 8 listopada) 1864 r. dotyczące kasaty zakonów obrządku łacińskiego w Królestwie Polskim nie wzmiankowały o unickich klasztorach bazylianów. W Petersburgu uważano, że sprawę bazylianów należy traktować odrębnie. Informację o decyzji cara w sprawie likwidacji bazyliańskich placówek przekazał w imieniu Aleksandra II 30 października (11 listopada) 1864 r. namiestnikowi Fiodorowi Bergowi sekretarz stanu do spraw Królestwa Polskiego Walerian Płatonowicz Płatonow. Postanowienie naczelnika $\mathrm{w}$ tej sprawie nosiło datę 28 listopada (10 grudnia) $1864 \mathrm{r}$. i składało się ze wstępu uzasadniającego motywy likwidacji oraz 15 punktów omawiających szczegóły organizacyjne przeprowadzenia kasaty. Namiestnik ogłaszał zniesienie pięciu męskich klasztorów bazyliańskich w Królestwie Polskim: Biała, Chełm, Lublin, Warszawa, Zamość. W uzasadnieniu decyzji wskazywano na zbyt małą liczbę zakonników w klasztorach, niewłaściwy zarząd placówek oraz działalność nieodpowiadającą przeznaczeniu. Zakonnikom zaproponowano przeniesienie się do placówki w Warszawie lub do klasztorów usytuowanych poza granicami Królestwa Polskiego wraz z ofertą zwrotu kosztów podroży. Władzom diecezjalnym zabroniono utrzymywania kontaktów ze zwierzchnikami zakonnymi. Majątki 
klasztorne przekazano pod zarząd Komisji Rządowej Przychodów i Skarbu. Dochody z majątków miały być przeznaczone na polepszenie sytuacji materialnej parafii i na utrzymanie placówki w Warszawie, w której mieli zamieszkać zakonnicy ze skasowanych klasztorów ${ }^{3}$.

Przeprowadzenie kasaty powierzono lokalnym władzom powiatowym na podstawie Reskryptu Komisji Rządowej Przychodów i Skarbu z 21 listopada (3 grudnia) 1864 r. oraz zarządzenia Gubernatora Cywilnego guberni lubelskiej z 17 (29) grudnia 1864 r. Na mocy tych dokumentów do Białej przybyli oddelegowani urzędnicy i poinformowali o kasacie pozostających $\mathrm{w}$ bialskim klasztorze zakonników: pełniącego funkcję przełożonego (superiora) Sofroniusza Trocewicza i pozostałych zakonników (P. Rzewuski, S. Wasilewski, S. Dekudowski, J. Starosełec, F. Troć, M. Trusiewicz, J. Włodawiec), prezentując owe działania jako „wypełnienie Najwyższej woli”. Następnie przedstawili oświadczenie o przejściu całego majątku pod zarząd władzy skarbowej i oznajmili duchownym, że „wszelkie stosunki z dotychczasową zwierzchnością klasztoru księży bazylianów ustają"4. O kasacie S. Trocewicz powiadomił konsystorz unickiej diecezji chełmskiej, na której obszarze usytuowany był klasztor ${ }^{5}$. Dla zapewnienia ciągłości opieki duszpasterskiej w parafii dotychczas prowadzonej przez bazylianów biskup chełmski Mikołaj Kaliński za pośrednictwem dziekana dekanatu bialskiego przesłał 24 grudnia 1864 r. decyzję o przekazaniu administracji parafii „,W rzeczach cywilnych i duchownych" zakonnikom pozostawionym w Białej".

Zasadniczym założeniem kasaty było pozbawienie możliwości działania zakonników zaangażowanych w działalność patriotyczną, kolidującą z założeniami polityki rosyjskiej. Aktywność bazylianów z bialskiego klasztoru została dostrzeżona przez władze rosyjskie w latach poprzedzających kasatę. 20 listopada (2 grudnia) $1861 \mathrm{r}$. aresztowani zostali dwaj zakonnicy: przełożony S. Trocewicz oraz P. Rzewuski. Pierwszy, zatrzymany z powodu tolerowania we wnętrzach bazyliańskiej cerkwi śpiewu zakazanych pieśni, został zwolniony po udzieleniu napomnienia przez naczelnika wojennego. Działalność drugiego zakonnika została przez Rosjan uznana za bardziej

\footnotetext{
${ }^{3}$ Центральний Державний Історичний Архів України у Львові [Tsentral'nyy Derzhavnyy Istorychnyy Arkhiv Ukrayiny u L'vovi], Lwów, Fond 201, opis 4b, sygn. 1403; P.P. GACH, Kasaty zakonów na ziemiach dawnej Rzeczypospolitej i Ślaska 1773-1914, Lublin 1984, s. 184-185.

${ }^{4}$ Archiwum Państwowe w Radomiu, Zarząd Dóbr Państwowych w Radomiu, Izba Skarbowa Siedlecka (dalej: APR, ZDP, ISS), sygn. 572, s. 13.

${ }^{5}$ Archiwum Państwowe w Lublinie, Chełmski Konsystorz Grecko-Katolicki (dalej: APL, ChKGK), sygn. 285, s. 40.

${ }^{6}$ Tamże, s. 37-39.
} 
szkodliwą. W grudniu 1861 r. został zesłany do Wołogdy. Do Białej powrócił z końcem lata 1862 r. i od 25 września tego roku był pod sekretnym dozorem policyjnym. Dotychczasowe doświadczenia P. Rzewuskiego wpłynęły na brak zaangażowania $\mathrm{w}$ powstanie styczniowe. Według informacji naczelnika powiatu z stycznia 1863 r. prowadził się wzorowo ${ }^{7}$.

Ważnym aspektem kasaty bazyliańskiej placówki w Białej było przeciwdziałanie rozwojowi, stanowiącego istotny element budowy tożsamości Cerkwi unickiej, kultu bł. Jozafata Kuncewicza, którego relikwie znajdowały się w bialskiej cerkwi bazylianów. W XIX wieku kult męczennika cieszył się znaczną popularnością wśród mieszkańców Białej i okolic. W drugiej połowie XIX stulecia nastąpiła jego intensyfikacja, kreująca zamordowanego przez prawosławnych mieszkańców Witebska w $1623 \mathrm{r}$. biskupa na bohatera w walce z „Moskalami”8. Nośność tej idei w szerokich kręgach społecznych godziła w rację stanu polityki Rosji. Rosyjska historiografia XIX stulecia dyskredytowała działania i postać Jozafata Kuncewicza ${ }^{9}$, a rosyjska administracja niszczyła przejawy pamięci i kultu. 21 listopada (3 grudnia) $1866 \mathrm{r}$. Główny Dyrektor Правительственной Комиссии Народного Просвещения [Prawitielstwiennoj Komissji Narodnogo Proswieszczenia], czyli rządowej komisji edukacji narodowej, zwrócił się do carskiego namiestnika Królestwa Polskiego Fiodora Berga, aby z racji kanonizacji Jozafata Kuncewicza skierował do hierarchów cerkiewnych eparchii zalecenie bezwzględnego zakazu jakichkolwiek procesji lub ceremonii odnoszących się do kanonizacji biskupa Jozafata „dla unikania nowych kolizji między dwoma różnymi narodowościami i wyznaniami”"

${ }^{7}$ A. KossowsKI, $Z$ dziejów unii kościelnej na terenie b. diecezji chetmskiej $w$ latach 18511866, Lublin 1939, s. 12; W. KoŁBuK, Bazylianie w Królestwie Polskim w latach 1817-1872, „Roczniki Humanistyczne” 31 (1983), z. 2, s. 167; E. NIEBELSKI, „Nieprzejednani wrogowie Rosji”. Duchowieństwo lubelskie i podlaskie w powstaniu 1863 roku i na zesłaniu, Lublin 2008, s. 105.

${ }^{8} \mathrm{O}$ znaczącym wpływie kultu Kuncewicza na kształtowanie postaw wiernych świadczy treść dokumentu z 1862 r. odnalezionego w latach siedemdziesiątych XX wieku podczas remontu kościoła w Bezwoli (w XVIII-XIX wieku była to parafia cerkiewna), w którym czytamy: „Zaklinamy was Imieniem Boga, żebyście stałemi byli w wierze świętej unickiej, na wzór waszych poprzedników obu stron uciśnionych prześladowanych, gdybyście wy doczekali takich czas ów, a może i gorszych, czego Boże uchowaj, gdyby przyszło do tego, żeby schizmatycy zmuszali do przyjęcia ich błędnej i fałszywej wiary, bądźcie trwałemi i nie odstępujcie nigdy swej wiary świętej, znoście prześladowania cierpliwie i mężnie na wzór naszego Świętego Józefata, który za stałość w wierze świętej unickiej był od Moskali zabity”. Za: J. WoŁODKo, Dokument z 1862 roku znaleziony w pounickim kościele w Bezwoli, „Radzyński Rocznik Humanistyczny” 3 (2005), s. 205-210.

${ }^{9}$ N. MorawIEc, Dekonstrukcje świętości. Jozafat Kuncewicz w rosyjskiej historiografii synodalnej, „Kultura Słowian. Rocznik Komisji Kultury Słowian PAU” 14 (2018), s. 80-97.

${ }_{10} \mathrm{AGAD}$, CWW, sygn. 248, О воспрещении помещать в святиах издаваемых молитвенников и календарей имен Йосафата Кунщевича и Андрея Боболи [O wosprieszczenii po- 
Kasata klasztoru skutkowała konfiskatą majątku. W przejęciu dóbr klasztornych wykorzystano dokumentację opracowaną na potrzeby administracji Królestwa Polskiego. Dokumentem stanowiącym punkt odniesienia w ustaleniu stanu majątkowego, dochodów i zobowiązań był protokół sporządzony 8 (20) maja 1859 r. według instrukcji do spisu majątku duchownego wydanej przez Komisję Rządową Spraw Wewnętrznych i Duchownych 5 (17) grudnia 1853 r. Protokół w formie spisu, jak również wykazu tabelarycznego wyczerpująco sporządzili członkowie komisji (w skład której wchodzili: dziekan dekanatu bialskiego ks. Symeon Jaroszewicz, proboszcz i superior bialskiej parafii S. Trocewicz, plenipotent dóbr Biała Stefan Buchowiecki, członkowie dozoru kościelnego Daniel Lubański i Mikołaj Szucki, rachmistrz Hieronim Czapiński) ${ }^{11}$. Zawartość inwentarzy sporządzonych w $1853 \mathrm{r}$. porównywano ze stanem bieżącym i w miarę potrzeby uzupełniano objaśnieniami. Licząca 23 karty dokumentacja opisująca majątek klasztoru w Białej na wniosek Generalnej Prokuratorii Królestwa Polskiego została również przekazana do pomocnika Siedleckiego Głównego Wydziału Wojennego ${ }^{12}$. Procedury przejęcia majątku klasztornego przemawiają za tym, że przeprowadzano je według uprzednio przygotowywanych koncepcji.

Oddelegowani urzędnicy zgodnie z instrukcją Rządu Gubernialnego przystąpili do przejęcia majątku klasztornego w następującym porządku: skontrolowali dokumenty odnoszące się do majątku klasztornego i skonfiskowali gotówkę (9 rb. 46 i pół kop.). Na podstawie dokumentów przechowywanych w klasztorze przejęli lokaty pieniężne zdeponowane w Banku Polskim, utworzone z zysków ze sprzedaży dzwonów dostarczonych w 1831 r. do arsenału i ze składki na remont cerkwi i ikonostasu (na 3\%), pieniądze lokowane na dobrach Mniszew (na 4\%) oraz środki pochodzące z zapisu fundacyjnego księżnej Anny z Sanguszków Radziwiłłowej (1676-1746), a następnie zatwierdzone na mocy wyroku Sądu Komisji do Urządzenia Interesów Radziwiłłowskich w 1825 r. Przejęto również majątek z usytuowanych w powiecie bialskim dóbr ziemskich Rososz i Korczówka, będących w posiadaniu bialskich bazylianów na mocy zapisu Bonifacego Ossolińskiego z 26 maja 1797 r. W 1844 r. pieniądze te zostały zdeponowane w Dyrekcji Głównej Towarzystwa Ziemskiego, a następnie odesłane do Banku Polskiego w formie oprocentowanych lokat. Przejęto również pienią-

mieszczat $w$ swiatcach izdawajemych molitwiennikow i kalendariej imien Josafata Kuncewicza i Andrieja Boboli], s. 7. Do innych diecezji 2-20.

${ }^{11}$ APR, ZDP, sygn. 13450, s. 6-9.

${ }^{12}$ Tamże, sygn. 13448, s. 45. 
dze zapisane na mocy testamentu na majątku w miejscowości Horbów, przekazane następnie do Banku Polskiego. W podsumowaniu majątek został oszacowany na $17402 \mathrm{rb}$. i $35 \mathrm{kop}$. Pieniądze zostały przejęte przez naczelnika wojennego i wpłacone do kasy powiatu bialskiego ${ }^{13}$.

Skrupulatnie zinwentaryzowano przechodzące pod zarząd skarbu nieruchomości służące klasztornemu gospodarstwu (kryty słomą drewniany dom folwarczny na podmurowaniu, kloaka, drewniany kurnik, drewniany spichlerz na podmurowaniu, drewniana obora kryta słomą, drewniana szopa, kryte słomą chlewy drewniane, stajnia, wozownia, dwie stodoły, dom murowany do połowy, pokryty dranicami drewniany dom przy ul. Brzeskiej $\mathrm{nr} 213$ ). Skonfiskowano budynki służące klasztorowi: oficynę murowaną z czterema pomieszczeniami oraz stajnię i wozownię, kuchnię przy ogrodzie klasztornym, usytuowaną na środku dziedzińca klasztornego ocembrowaną studnię z żurawiem. Ogółem wartość budynków oszacowano na $1640 \mathrm{zz}^{14}$.

Kasatą objęto 180 mórg gruntów i łąk oraz usytuowane w mieście trzy ogrody należące do klasztoru. Z związku z tym, że grunty te nie były opomiarowane, dokonano inspekcji $\mathrm{z}$ udziałem przełożonego klasztoru S. Trocewicza. Przejęto również inwentarz ( 2 konie, 3 woły, 3 krowy, 4 sztuki trzody chlewnej) oraz plony (30 kop snopów żyta ozimego, 1 kopę jarego, 10 kop jęczmienia, 1 furę słomy oraz w ziarnie: pszenicę, żyto, owies, jęczmień, gryka, groch) i utensylia domowe wycenione na $269 \mathrm{rb}^{15}$.

Sporządzono skrupulatny inwentarz wyposażenia ruchomego przejętych budynków oraz dokonano ich wyceny i następnie wystawiono na licytację. Struktura opisu ruchomości może świadczyć, że działano w pośpiechu. Nie dokonano żadnej klasyfikacji grupowej czy rzeczowej. Spisu dokonano według pomieszczeń, w których się znajdowały. 7 III 1865 r. w trybie licytacji na sprzedaż wystawiono meble, naczynia, sztućce, zastawy stołowe. Rozprzedawano najdrobniejsze rzeczy gospodarstwa klasztornego. Nabywcami byli zapewne okoliczni mieszkańcy. Ten sposób zbywania mienia klasztornego miał ważny wymiar oddziaływania społecznego i stanowił manifestację deprecjacji społecznej zakonników. Według dołączonego protokołu zysk z licytacji wyniósł 364 rb 33 kop. ${ }^{16} \mathrm{Z}$ licytacji wyłączono obrazy o tematyce religijnej (10 obrazów ilustrujących przykazania Boże, obraz Wniebowzięcia Matki Boskiej, obraz Matki Boskiej haftowany jedwabiem, obraz Matki Boskiej w sukience pozłacanej z kamieniami, mały, okrągły

\footnotetext{
${ }^{13}$ Tamże, ISS, sygn. 572, s. 16-17.

${ }^{14}$ Tamże, s. 17, 20.

15 Tamże, s. 18, 20-21.

${ }^{16}$ Tamże, s. 32.
} 
obraz Matki Boskiej, obraz Matki Boskiej na płótnie, lusterko w ramach, 5 obrazów świętych, m.in. św. Bazylego na płótnie), 3 tablice z modlitwami, 2 portrety Radziwiłłów malowane na płótnie, 2 portrety litografowane w ramach biskupów diecezji chełmskiej: unickiej Ferdynanda Dąbrowy Ciechanowskiego (1810-1828) i łacińskiej Feliksa Turskiego (1765-1771). Do dyspozycji zakonników pozostawiono część umeblowania (stoły, fotel, kanapa) oraz zegar w szafie ${ }^{17}$. Trudno rozstrzygnąć, jakimi kryteriami kierowano się przy wyłączeniu tych ruchomości z licytacji: czy zdecydowały potrzeby zakonników, czy przewidywania, że rzeczy te nie znajdą nabywców i poprzez naruszenie zasad dotychczasowego porządku społeczno-ideowego mogą wzbudzić niechęć lokalnej społeczności.

Wraz z przejęciem majątku klasztornego gospodarstwo klasztorne opuściła 12-osobowa służba, co uniemożliwiło jego dalsze funkcjonowanie. W związku z brakiem obsługi gospodarstwa poklasztornego zarządzono publiczną licytację inwentarza żywego oraz plonów. Inwentarz żywy zlicytowano 7 (29) marca 1865 r., uzyskując ze sprzedaży sumę 113 rb. Tego dnia ogłoszono również publiczną licytację zboża oraz sprzętów ze zlikwidowanego gospodarstwa klasztornego. Na sprzedaż wystawione zostały m.in. beczki po piwie, ogórkach, kapuście, burakach, półki, „bijanka” do masła, stoły do suszenia mąki, patelnie, tygle, piecyk do palenia kawy, młynek do kawy, magiel drewniany, sochy do orania, 3 wozy jednokonne, 3 chomąta, 3 sieczkarnie, moździerz. Przedmioty z gospodarstwa klasztornego chętnie kupowano i nie było problemu z ich zbyciem. Przystępującym do licytacji przedmioty były wydane natychmiast. Wśród nabywców odnotowano osoby o następujących nazwiskach: Herman, Sasow, Bassow, Siergiejew, Nornheim, Mandelbaum, Moszko Rosenberg, Kirylinn, Starkiewicz, Stefan Abramowicz, Mitenbaum, Gdala Fonia [?], Grzebulinicki, Przesmycki. Znaczący udział w gronie nabywców poklasztornego mienia przedstawicieli społeczności żydowskiej mógł przyczyniać się do tworzenia postaw antysemickich wśród chrześcijańskiej społeczności Białej i okolic.

Kilka sprzętów podczas licytacji nabył o. S. Trocewicz (m.in. zegar ścienny). 29 marca (10 kwietnia) 1865 r. zyski uzyskane z licytacji w wysokości 260 rb. i 24 1/2 kop. zostały wpłacone przez asesora ekonomicznego Aleksandra Kurcewicza do kasy powiatu bialskiego. Suma ze sprzedaży inwentarza poklasztornego wyniosła $362 \mathrm{rb}$. i 33 kop. ${ }^{18}$ Zyski zostały przekazane do depozytu kasy powiatu bialskiego. Włościanie pozostający na

\footnotetext{
${ }^{17}$ Tamże, s. 31.

${ }^{18}$ Tamże, s. 33.
} 
gruntach klasztornych w Sielcu zostali uwłaszczeni. Do dyspozycji zakonników utrzymanych przy parafii pozostawiono usytuowany przy cerkwi budynek klasztoru, ogród owocowy i warzywny z domem ogrodnika i dwie kryte gontem, murowane piwnice ${ }^{19}$.

Wraz $\mathrm{z}$ podejmowanymi działaniami zabezpieczano dokumentację. 27 lutego (11 marca) 1865 r. do Rządu Gubernialnego Lubelskiego asesor ekonomiczny powiatu bialskiego A. Kurcewicz przesłał tzw. dowody do protokołu szczegółowego przyjęcia w Zarząd Skarbu majątku klasztoru księży bazylianów w Białej. Licząca 87 kart dokumentacja została parafowana i opieczętowana. Do dokumentacji załączono tzw. konsygnacje dowodów do protokółu lustracji ${ }^{20}$. Aparat biurokratyczny realizujący kasatę wykazał się skrupulatnością i drobiazgowością, gromadząc wyczerpującą dokumentację. Poprzez swoje zaangażowanie uzasadniał również, oprócz sprawności przy realizacji celów polityki rosyjskiej, potrzebę swojego funkcjonowania w rozbudowanym wymiarze. Odpowiedzialność za decyzję władz rosyjskich rozkładano na lokalne władze duchowne i powiatowe. Przy sporządzaniu protokołu ogłoszenia przejścia majątku bialskich bazylianów „pod zupełny zarząd władzy skarbowej Królestwa” (12 [24] marca 1865 r.) obecni byli: delegat duchowny ks. Grzegorz Karpowicz, naczelnik wojenny powiatu bialskiego Łacki [?], burmistrz Białej Filip Rabczewski, ławnik bialskiego sądu Daniel Lubański, pełnomocnik naczelnika powiatu bialskiego Narcyz Zaborowski, urzędnik skarbowy A. Kurcewicz ${ }^{21}$. O przebiegu kasaty poinformowany został biskup unickiej diecezji chełmskiej, który otrzymał 2 (14) czerwca 1865 r. szczegółową informację ks. Karpowicza, który zwracał uwagę, że do spuścizny klasztoru należały również zobowiązania modlitewne, tzw. obligi, których zaległych do odprawienia pozostało 931 spośród zamówionych dawniej i 430 zamówionych za rządów ostatniego

\footnotetext{
${ }^{19}$ Tamże, s. 7, 17.

${ }^{20}$ Tamże, s. 9-10. Były to następujące dokumenty: dokument erekcyjny księcia Karola Stanisława Radziwiłła z 15 maja 1696 r., Zapis ogrodu i łąki przez Rozalię Szawuowiczową, Inwentarz opisu majątku księży bazylianów, Regestr klasyfikacyjny gruntów i łąk z wyrachowaniem intraty, Wykaz ogrodzeń znajdujących się przy klasztorze, Odezwa administratora dóbr Białej w sprawie pastwiska, Odpowiedź administratora lasów bialskich, Odezwa administratora dóbr Biała, Odpowiedź magistratu w Białej względem opłaty czynszu za zajęty lokal na szkółkę grecko-unicką, Książki służbowe (12 szt.), Odezwa naczelnika powiatu bielskiego z rachunkiem, Regestr książek znajdujących się w bibliotece, Świadectwo kasy powiatu bialskiego o wysokości opłacanych podatków skarbowych, Świadectwo magistratu miasta Białej o opłacie składki ogniowej, Odezwa administratora dóbr Białej co do opłaty czynszu.

${ }^{21}$ Tamże, s. 32.
} 
superiora. S. Trocewicz pieniądze z opłat wniesionych za te posługi religijne przeznaczył na bieżące potrzeby klasztoru ${ }^{22}$.

Komisja dokonująca inwentaryzacji majątku klasztoru skontrolowała również zasób biblioteki klasztornej. Podstawą do weryfikacji zasobu był katalog sporządzony w 1836 r., uwzględniający podział księgozbioru według 18 sekcji tematycznych. W efekcie kontroli stwierdzono obecność w klasztornej bibliotece 674 książek. Konfrontacja z katalogiem wykazała brak 124 książek $^{23}$. Ponadto w bibliotece odnaleziono książki nieobjęte spisem z 1836 r., woluminy bez tytułów oraz podręczniki szkolne w liczbie 26 sztuk. Oprócz książek w zasobach biblioteki odnotowano 48 rękopisów „w zeszytach” oraz 9 rękopisów w języku „słowiańskim”. Po inwentaryzacji pomieszczenie biblioteki zostało zamknięte i zapieczętowane. Klucz został przekazany przełożonemu o. S. Trocewiczowi ${ }^{24}$.

Przejęte $w$ efekcie kasaty budynki i grunty wymagały utrzymania ciągłości zagospodarowania. 2 (14) kwietnia 1865 r. władze skarbowe powiatu bialskiego zawarły kontrakt z Ignacym Romaniukiem, którym został on zobowiązany, w zamian za pensję oraz prawo do zamieszkania, do podjęcia obowiązków stróża pobazyliańskich zabudowań skarbowych, kontroli zasiewów i łąk w celu zapobiegania szkodom, oczyszczania przynajmniej raz na tydzień bruków na ul. Brzeskiej, przy której usytuowane były zabudowania, i dziedzińca folwarcznego.

Do prac $\mathrm{w}$ gospodarstwie poklasztornym zatrudniano dorywczo różne osoby. 30 kwietnia (12 maja 1865 r.) celem zasiewu gruntów poklasztornych mieszkaniec Białej Szmul Fiszman zakupił zboże i zatrudnił do wykonywania prac gospodarskich okoliczną ludność. Był to doraźny sposób na zagospodarowanie przejętych gruntów. 17 (29) maja 1865 r. asesor ekonomiczny powiatu bialskiego skierował do wójtów gmin i magistratów miast guberni siedleckiej obwieszczenie o licytacji na wydzierżawienie w bieżącym roku zbiorów w majątku po klasztorze bazylianów w Białej. O trudnościach z przejęciem majątku klasztornego informował 4 (16) czerwca $1865 \mathrm{r}$. asesor ekonomiczny powiatu bialskiego w raporcie do Urzędu Gubernialnego Lubelskiego, donosząc, że „cała służba rozeszła się”, co spowodowało potrzebę natychmiastowej sprzedaży inwentarza i wynajęcia do prac wiosennych pracowników ${ }^{25}$. Rozwiązaniem tej sytuacji miało być czasowe powo-

\footnotetext{
${ }^{22}$ APL, ChKGK, sygn. 687, s. 29-30.

${ }^{23}$ Tamże.

${ }^{24}$ APR, ZDP, ISS, sygn. 572, s. 23-28.

${ }^{25}$ Tamże, s. 40, 115, 119.
} 
łanie na administratora dóbr zakonnych Michała Nernhajma, który został zobowiązany do złożenia przysięgi, w której zobowiązywał się, że nie narazi skarbu na straty. Ostatecznie grunty zostały na rok wydzierżawione Kazimierzowi Mleczce $\mathrm{w}$ zamian za opłatę podatków i czynszu za dzierżawę w wysokości 105 rb. ${ }^{26}$ Kazimierz Mleczko czerpał zyski z podnajmu budynków poklasztornych Szumanowi Jarnickiemu i Elemu Lejbkowiczowi ${ }^{27}$.

W 1866 r. do sprzedaży przygotowywane były grunty poklasztorne. Rząd Gubernialny Siedlecki z upoważnienia Komisji Rządowej Przychodów i Skarbu, działając na mocy przepisów ukazu z 27 października (8 listopada) 1864 r. o klasztorach rzymskokatolickich w Królestwie Polskim, z zastosowaniem rozporządzenia Komitetu Urządzającego z 30 kwietnia (12 maja) 1866 r., wystawił na sprzedaż w drodze publicznej licytacji zajęte dobra: pola uprawne, łąki, ogrody, pastwiska, z których dochód roczny oszacowano na 105 rub. Licytację wyznaczono na dzień 22 maja 1867 r. o godzinie $12 \mathrm{w}$ biurze Rządu Gubernialnego w Siedlcach. Przystępujący do licytacji byli zobowiązani do złożenia kopert w dniu licytacji do godziny 12. Wysokość wadium wyznaczono na 262,5 rb. Zaznaczono, że prawo użytkowania nabywcy nastąpi po wpłaceniu całości kwoty. Nabywca zobowiązany był do płacenia podatków na ogólnie przyjętych zasadach ${ }^{28}$. Z niewiadomych wzglądów licytacja nie została rozstrzygnięta - czy był to brak możliwości nabywczych z racji ekonomicznych, czy też efekt barier mentalnych, które nie pozwalały na zakup mienia poklasztornego. Inną przyczyną niesfinalizowania zbycia gruntów majątku poklasztornego mogła być zmiana koncepcji funkcjonowania ośrodka parafialnego w Białej. Decyzją Dyrektora Głównego Prezydującego w Komisji Rządowej Spraw Wewnętrznych i Duchownych z 27 czerwca (9 lipca) 1868 r. grunty poklasztorne zostały przekazane na uposażenie proboszcza pobazyliańskiej parafii w Białej ks. Michała Liwczaka. Na jego prośbę o zapewnienie mu lepszych warunków lokalowych i pomieszczeń gospodarczych oddelegowana komisja dokonała podziału: gmach poklasztorny i przyległy dom przekazano w użytkowanie proboszcza, natomiast odrębny budynek przy ul. Brzeskiej na potrzeby szkoły ${ }^{29}$. Zgodę na zatrzymanie 240 mórg ziemi na potrzeby utrzymania ks. M. Liwczaka w 1868 r. wydały władze guberni siedleckiej ${ }^{30}$.

\footnotetext{
${ }^{26}$ Tamże, sygn. 630, s. 4, 7-11.

${ }^{27}$ Tamże, s. 48-52.

${ }^{28}$ Tamże, s. 4-6.

${ }^{29}$ Tamże, s. 48-55.

${ }^{30}$ Tamże, s. 20-21.
} 
Brak bezpośrednio po kasacie materialnych podstaw w znaczącym stopniu wpływał na obniżenie poziomu pracy duszpasterskiej i stanowił utrudnienie dla pozostających przy parafii zakonników. S. Trocewicz w korespondencji z 28 kwietnia (10 maja) 1865 r. skierowanej do nominata unickiej diecezji chełmskiej Jana Kalińskiego pisał: „z tego co wiele lat zbieraliśmy z trudem i oszczędnością nie tylko nic nie mamy, ale jesteśmy pozbawieni wielu przedmiotów" i informował, że parafia i cerkiew pozbawione są należytej obsługi, co wpływa na zdemoralizowanie i zobojętnienie religijne. Przy cerkwi brakowało diaka, zakrystiana, a w konsekwencji możliwości należytego sprawowania liturgii. Wypłacana o. S. Trocewiczowi pensja umożliwiała mu tylko utrzymanie zakrystiana. S. Trocewicz informował, że po sprzedaży koni klasztornych nie miał możliwości obsługi chorych na rozległym obszarze parafii, a po wydzierżawieniu zabudowań - został pozbawiony kuchni, szopy na drewno, stajni i chlewika. W związku z tym prosił biskupanominata o interwencję $\mathrm{u}$ władz rządowych $w$ następujących sprawach: funduszu na utrzymanie diaka, zakrystiana i „dziada” oraz umożliwienie im zamieszkania przy cerkwi, ułatwień $\mathrm{w}$ zakupie wina na potrzeby liturgii, umożliwienia zakupu koni, bryczki i ich utrzymania, funduszu na utrzymanie furmana i budowę $\mathrm{w}$ klasztorze nowej kuchni oraz pomieszczeń gospodarczych $^{31}$.

W drugiej połowie 1865 r. zakonnicy zostali odsunięci od posługi duszpasterskiej, a zarząd nad parafią przejął ks. Michał Liszkiewicz. Pomimo pozbawienia możliwości działalności zakonnicy w Białej pozostawali jeszcze kilka miesięcy, co poświadcza treść dokumentu skierowanego 22 stycznia (3 lutego) 1866 r. do nowego proboszcza, informującego o decyzji przyznania wypłaty na rok 1866 każdemu z 7 duchownych w cerkwi pobazyliańskiej, w tym P. Rzewuskiemu i S. Trocewiczowi, po 150 rub. rocznie. Wkrótce (przed 4 [16] marca 1866 r.) z rozkazu naczelnika wojennego powiatu bialskiego z Białej do Warszawy został wywieziony S. Trocewicz oraz prawdopodobnie pozostali zakonnicy, z wyjątkiem F. Trocia, który zdecydował się na opuszczenie zakonu ${ }^{32}$. Prawdopodobnie odbyło sie to z zaskoczenia, skoro uprzednio przyznano duchownemu całoroczną pensję. Decyzją władz z 11 kwietnia 1866 r. S. Trocewicz został skierowany do małej i słabo uposażonej parafii unickiej w swoje rodzinnej miejscowości,

\footnotetext{
${ }^{31}$ APL, ChKGK, sygn. 215, s. 49-50.

${ }^{32}$ APL, ChKGK, sygn. 215, s. 46, 53-54; B. PietnoczKo, Bazylianie polscy. Ostatnie lata w Królestwie, w: Śladami unii brzeskiej, red. R. Dobrowolski, M. Zemło, Lublin-Supraśl 2010, s. 401.
} 
Rogowie, usytuowanej z dala od centrów administracyjnych i religijnych. Dwaj zakonnicy z bialskiego klasztoru: sprawujący posługę kaznodziei Sebastian Wasilewski i P. Rzewuski zostali internowani w Radecznicy ${ }^{33}$. Odosobnienie w miejscu oddalonym od Białej i skutecznie uniemożliwiało im działalność. P. Rzewuski w 1875 r. był jednym z 5 bazylianów (a w ogóle jednym z 69 duchownych unickich), którzy nie przyjęli prawosławia, pozostając pod nadzorem policji, bez środków utrzymania.

W tym czasie, kiedy proboszczem bialskiej parafii był ks. Michał Liszkiewcz, na początku $1866 \mathrm{r}$. z wnętrza bialskiej cerkwi na rozkaz naczelnika wojennego powiatu bialskiego usunięto obraz Józefa Simmlera przedstawiający śmierć Jozafata Kuncewicza. Wizerunek ten został umieszczony we wnętrzach bialskiej cerkwi 26 września 1861 r. przez biskupa łacińskiej diecezji janowskiej, czyli podlaskiej, Piotra Pawła Beniamina Szymańskiego. Wydarzeniu nadano uroczystą oprawę, która zgromadziła wielu wiernych obrządku łacińskiego i greckiego. Obraz został odesłany do Warszawy, a następnie do Moskwy do Muzeum Rumiancewa. Odzyskany został w 1921 r. $^{34}$

W 1867 r. parafię w Białej objął, cieszący się szczególnym zaufaniem władz rosyjskich, pochodzący z Galicji ks. M. Liwczak. Jego przybycie do Białej nastąpiło w momencie, gdy miejscowa ludność unicka zaczęła protestować przeciwko usuwaniu ze świątyni obcych prawosławnej tradycji elementów wyposażenia wnętrza i zlatynizowanych obrzędów typowych dla unickiej diecezji chełmskiej. Ks. M. Liwczak wyróżniał się zaangażowaniem w zwalczanie unickich tradycji w swojej parafii. W 1869 r. nie zorganizował uroczystości Bożego Ciała, za co naraził się biskupowi chełmskiemu Mychajle Kuzemskiemu. 12 stycznia 1875 r. kierowana przez ks. M. Liwczaka parafia w Białej jako pierwsza placówka unicka ogłosiła przejście na prawosławie (miało to miejsce cztery miesiące przed oficjalną likwidacją unickiej diecezji chełmskiej). Uroczysta konwersja odbyła się w cerkwi bialskiej w obecności arcybiskupa warszawskiego Joannicjusza, który słysząc wiernopoddańczą mowę ks. M. Liwczaka, był zniesmaczony jego serwilizmem. $Z$ parafią bialską prawosławie przejęło 50 tys. wiernych unitów z 45 parafii, jak również 26 kapłanów ${ }^{35}$. Bialski sobór, dzięki wsparciu

\footnotetext{
${ }^{33}$ W. KoŁBuK, Bazylianie w Królestwie Polskim, s. 172-184.

${ }^{34}$ J.M. CyGan, Beniamin Szymański, kapucyn, biskup podlaski, ,Szkice Podlaskie” 5 (1996), s. 110-119; J. LewANDOwski, Na pograniczu. Polityka władz państwowych wobec unitów Podlasia $i$ Chetmszczyzny 1772-1875, Lublin 1996, s. 88; APL, ChKGK, sygn. 215, s. 51-52.

${ }^{35}$ W. OsADCZY, Święta Ruś. Rozwój i oddziatywanie idei prawosławia w Galicji, Lublin 2007, s. 224, 228-229; J. LeWANDOWSKI, Na pograniczu. Polityka władz państwowych, s. 114, 118.
} 
władz rosyjskich, był ważnym i wyróżniającym się aktywnością ośrodkiem szerzenia prawosławia oraz miejscem manifestacji poparcia rosyjskiego imperializmu $^{36}$.

Wybór Białej na centrum działań Cerkwi prawosławnej był nawiązaniem do tradycji Cerkwi unickiej, w której klasztor bazyliański, z racji przechowywanych relikwii i prowadzonej przez zakonników działalności misyjnej, był ważnym ośrodkiem życia religijnego dla okolicznych parafii unickich. Powierzenie bialskiej parafii lojalnemu duchownemu wynikało przede wszystkim z dążenia do stworzenia warunków uniemożliwiających zorganizowanie obchodów z okazji ogłoszonej 29 czerwca 1867 r. kanonizacji Jozafata Kuncewicza. Dokonując kanonizacji, Stolica Apostolska chciała wzmocnić znaczenie jego kultu dla postawy unitów broniących się przed przymusem przejścia do Cerkwi prawosławnej. Lojalny wobec władz carskich ks. M. Liwczak, zgodnie z oczekiwaniami, aby nie nadawać rozgłosu kanonizacji Kuncewicza nie zorganizował $\mathrm{z}$ tej okazji żadnych ceremonii o charakterze religijnym ${ }^{37}$. Kolejnym krokiem mającym doprowadzić do eliminacji kultu czczonego w Cerkwi unickiej męczennika była decyzja Ministra Народного Просвещения [Narodnogo Proswieszczenia] o remoncie wnętrzu cerkwi, w trakcie którego usunięto relikwie Kuncewicza. Przed przeniesieniem otworzono relikwiarz, przeprowadzono oględziny, sporządzono protokół i dokonano zapieczętowania ${ }^{38} .26$ maja $1873 \mathrm{r}$. trumnę z relikwiami przeniesiono do krypt bialskiej cerkwi i zamurowano. W świetle raportu przesłanego do władz guberni siedleckiej przy przenoszeniu relikwii obecny był dziekan dekanatu bialskiego ks. Porfiriusz Filewicz i proboszcz bialskiej parafii ks. M. Liwczak. Obecni od godzin porannych w cerkwi wierni, reprezentanci miejscowości z parafii, oraz członkowie bractwa nie chcieli uczestniczyć w przenoszeniu і „не сделали ни шагу [nie sdiełali ni szagu]”. Po telegramie ponaglającym o trzeciej po południu przybył dziekan dekanatu Konstantynów ks. Mikołaj Kalinowski i przy pomocy strażników zapieczętował przeniesioną już do krypt trumnę. Klucze do podziemi przejął majster robót cerkiewnych, a grupa około 30 mężczyzn spokojnie rozeszła się do domów $^{39}$. W świetle wspomnień spisanych 13 października 1884 r. przez

${ }^{36}$ P. SĘCZYK, Zarys historyczny parafii prawosławnego Soboru Katedralnego Narodzenia NMP w Biatej Podlaskiej w latach 1875-1917, „Annales Universitatis Mariae Curie-Słodowska, 69 (2014), z. 1-2, sectio F, s. 135-149.

${ }^{37}$ A.P. DyDycz, Opisanie odnalezienia relikwii św. Jozafata Kuncewicza na tle jego życia oraz dziejów jego doczesnych szczątków, „Rocznik Bialskopodlaski” 12 (2004), s. 165-166.

${ }^{38}$ APL, ChKGK, sygn. 285, s. 373-374.

${ }^{39}$ Tamże, s. 375-377. 
unickiego duchownego z Międzyrzeca Podlaskiego ks. Faustyna Hanytkiewicza, pomimo zapewnień ks. Liwczaka, że po odrestaurowaniu cerkwi relikwie powrócą do jej wnętrza i zostaną wystawione na widok publiczny, obietnic tych nie spełniono, „grób świętego potrójnym osłonięto murem”. Opinia publiczna nie była informowana na temat losów relikwii ${ }^{40}$,

Pamięć o odpustach i pielgrzymkach do relikwii męczennika była żywa. W 1878 r. na wrześniowe ceremonie odpustowe przybyła grupa pielgrzymów z guberni grodzieńskiej z okolic Bielska. Przybycie pielgrzymów wzbudziło zaniepokojenie ks. Liwczaka, który podjął interwencję u duchownych i państwowych władz zwierzchnich, aby uniemożliwiły przybywanie wiernym do Białej $^{41}$.

Relikwie św. Jozafata Kuncewicza zostały wydobyte z podziemi cerkwi dopiero po opuszczeniu Białej przez Rosjan podczas I wojny światowej i wywiezione w 1917 r. do Wiednia, a następnie w 1949 r. do Rzymu, gdzie spoczywają do dzisiaj w Bazylice św. Piotra. W II Rzeczpospolitej budynek cerkwi pobazyliańskiej został przejęty na potrzeby kultu przez kościół rzymskokatolic$\mathrm{ki}$, a budynki poklasztorne czasowo były wykorzystywa na potrzeby wojska ${ }^{42}$.

Księgozbiór bialskich bazylianów został przekazany prawdopodobnie bezpośrednio po kasacie unickiemu seminarium duchownemu w Chełmie. Pozostająca pod nadzorem rządowym placówka w 1875 r. została przekształcona na seminarium prawosławne ${ }^{43}$. Po I wojnie światowej wraz z pozostałym zasobem chełmskiego seminarium został przekazany Wojewódzkiej Bibliotece Publicznej im. Hieronima Łopacińskiego w Lublinie. Obecnie w katalogu tej placówki zostały odnotowane 224 książki. Siedem z nich przekazano do Książnicy Zamojskiej im. Stanisława Kostki Zamoyskiego w Zamościu jako część. tzw. księgozbioru klemensowskiego, przekazanego w depozyt bibliotece przez rodzinę Zamoyskich, reprezentowaną przez prezydenta Zamościa Marcina Zamoyskiego. Relikty spuścizny rękopiśmiennej z bialskiej biblioteki bazylianów znajdują się w zasobach Wojewódzkiej Biblioteki Publicznej im. Hieronima Łopacińskiego w Lublinie (trzy rękopisy sporządzone w języku łacińskim) i Bibliotece Seminarium Metropolitarnego w Lublinie ${ }^{44}$, w której na podstawie adnotacji umieszczonych

${ }^{40}$ Wojewódzka Biblioteka Publiczna im. Hieronima Łopacińskiego w Lublinie, rkps. sygn. 2163, Ludwik Zaleski, Materiały i notaty różne, s. 800.

${ }^{41}$ APL, Chełmski Zarząd Duchowny, sygn. 1225, s. 1-16.

${ }^{42}$ Archiwum Diecezji Siedleckiej (dalej: ADS), B.IV.1, t. I, brak pag.

${ }^{43}$ W. OsADCZY, Święta Ruś, s. 358-359.

${ }^{44}$ Katalog rękopisów Biblioteki Seminarium Metropolitarnego w Lublinie, oprac. H.D. Wojtyska, ,ABMK”, 28-30 (1975), s. 127, 143, 151, 158, 161, 164, 271. 
w rękopisach pięć zostało identyfikowanych jako spuścizna bialskiej biblioteki bazylianów. Dwa rękopisy związane z działalnością bazyliańskiej placówki w Białej znajdują się w zasobach Archiwum Diecezjalnego w Siedlcach (księga przychodów i rozchodów odnotowująca rachunki klasztorne z lat 1766-1795 oraz kronika klasztorna, odnotowująca wydarzenia z lat 1800-1820 w językach łacińskim i polskim) ${ }^{45}$.

Analiza procesu kasaty klasztoru bazylianów w Białej może świadczyć o istotnej roli, jaką likwidacja tej placówki odegrała w realizacji celów politycznych Rosji. Efektem kasaty były wymierne korzyści finansowe wpływające do skarbu Królestwa Polskiego. Likwidacja klasztoru bazylianów w Białej wywołała nieodwracalne zmiany w życiu religijnym i krajobrazie kulturowym regionu.

\section{BIBLIOGRAFIA}

\section{ŹRÓDŁA RĘKOPIŚMIENNE}

Archiwum Diecezji Siedleckiej, sygn. B.IV.1, t. I; Varia, sygn. 6.

AGAD, Centralne Władze Wyznaniowe, sygn. 248.

Archiwum Państwowe w Lublinie:

Chełmski Konsystorz Grecko-Katolicki, sygn. 215, 285, 687.

Chełmski Zarząd Duchowny, sygn. 1225.

Archiwum Państwowe w Radomiu:

Zarząd Dóbr Państwowych w Radomiu, sygn. 13448, 13450.

Zarząd Dóbr Państwowych w Radomiu, Izba Skarbowa Siedlecka, sygn. 572, 630.

Wojewódzka Biblioteka Publiczna im. Hieronima Łopacińskiego w Lublinie:

rkps. sygn. 2163, Ludwik Zaleski, Materiały i notaty różne.

Центральний Державний Історичний Архів України у Львові, Fond 201, opis 4b, sygn. 1403.

$$
\text { ŹRÓDŁA DRUKOWANE }
$$

Volumina Legum, t. 5, Petersburg 1860.

\section{OPRACOWANIA}

BIEŃKowsKi Ludomir, Organizacja Kościoła wschodniego w Polsce, w: Kościół w Polsce, t. II: Wiek XVI-XVIII, red. J. Kłoczowski, Kraków: Znak 1968, s. 781-1049.

Cygan Jerzy M., Beniamin Szymański, kapucyn, biskup podlaski, „Szkice Podlaskie” 5 (1996), s. $110-119$.

\footnotetext{
${ }^{45}$ ADS, Varia, sygn. 6.
} 
Dydycz Antoni Pacyfik, Opisanie odnalezienia relikwii św. Jozafata Kuncewicza na tle jego życia oraz dziejów jego doczesnych szczątków, „Rocznik Bialskopodlaski” 12 (2004), s. 159-176.

GaCH Piotr Pawel, Kasaty zakonów na ziemiach dawnej Rzeczypospolitej i Śląska 1773-1914, Lublin: Redakcja Wydawnictw KUL 1984

KoŁBuK Witold, Bazylianie w Królestwie Polskim w latach 1817-1872, „Roczniki Humanistyczne" 31 (1983), z. 2, s. 153-185.

KossowsKi Aleksander, $Z$ dziejów unii kościelnej na terenie b. diecezji chetmskiej w latach 18511866, Lublin: Drukarnia „Narodowa” 1939.

Lewandowski Jan, Na pograniczu. Polityka władz państwowych wobec unitów Podlasia i Chetmszczyzny 1772-1875. Lublin: Wydawnictwo UMCS 1996.

MorawIEC Norbert, Dekonstrukcje świętości. Jozafat Kuncewicz w rosyjskiej historiografii synodalnej, „Kultura Słowian. Rocznik Komisji Kultury Słowian PAU” 14 (2018), s. 80-97.

NIEBELSKI Eugeniusz, „Nieprzejednani wrogowie Rosji”. Duchowieństwo lubelskie i podlaskie w powstaniu 1863 roku i na zestaniu, Lublin: Wydawnictwo KUL 2008.

OSADCZY Włodzimierz, Święta Ruś. Rozwój i oddziaływanie idei prawosławia w Galicji, Lublin: Wydawnictwo UMCS 2007.

PietnoczKo Bogdan, Bazylianie polscy. Ostatnie lata w Królestwie, w: Śladami unii brzeskiej, red. R. Dobrowolski, M. Zemło, Lublin-Supraśl: Wydawnictwo KUL 2010, s. 369-407.

SĘCZYK Piotr, Zarys historyczny parafii prawosławnego Soboru Katedralnego Narodzenia NMP w Białej Podlaskiej $w$ latach 1875-1917, „Annales Universitatis Mariae Curie-Słodowska, 69 (2014), z. 1-2, sectio F, s. 135-149.

WarchoŁ Stefan, Nazwy miast Lubelszczyzny, Lublin: Wydawnictwo Lubelskie 1964.

WoJTYSKA Henryk Damian, Katalog rękopisów Biblioteki Seminarium Metropolitarnego w Lublinie, „Archiwa, Biblioteki i Muzea Kościelne” 30 (1975), s. 133-194.

WoŁodKo Janusz, Dokument z 1862 roku znaleziony w pounickim kościele w Bezwoli, „Radzyński Rocznik Humanistyczny” 3 (2005), s. 201-210.

\section{KASATA KLASZTORU BAZYLIANÓW W BIAŁEJ PODLASKIEJ}

Streszczenie

Artykuł przedstawia proces realizacji kasaty klasztoru bazylianów w Białej Podlaskiej w aspekcie prawno-formalnym z uwzględnieniem kontekstu przemian politycznych i społecznych. Opisuje losy majątku klasztornego: nieruchomości i ruchomości klasztoru, budynku cerkwi i jego wyposażenia, losy księgozbioru biblioteki klasztornej. Przedstawia postawy zakonników wobec kasat oraz ich losy po opuszczeniu Białej Podlaskiej. Kasata bialskiej placówki wpisywała się w założenia polityki rosyjskiej, prowadzącej do likwidacji Cerkwi unickiej i wygaszenia kultu bł. Jozafata Kuncewicza, którego relikwie znajdowały się w bialskiej cerkwi i były otaczane szczególną czcią przez wiernych katolików zarówno obrządku łacińskiego, jak i greckiego. Likwidacja placówki z Białej Podlaskiej na trwale zmieniła krajobraz religijny i kulturowy miasta i okolic.

Słowa kluczowe: bazylianie; Cerkiew unicka; klasztor bazyliański w Białej Podlaskiej; biblioteka klasztoru bazyliańskiego w Białej Podlaskiej; Jozafat Kuncewicz. 


\section{DISSOLUTION OF THE BASILIAN MONASTERY \\ IN BIAŁA PODLASKA}

\section{S u m m a ry}

This paper presents the process of dissolution of the Basilian monastery in Biała Podlaska in the legal and formal aspect, taking into account the context of political and social changes. It describes the lot of the monastery property, its immovables and movables, the building of the church and its equipment, as well as the monastery library. It presents also the attitudes of monks towards dissolution and their fate after leaving Biała Podlaska. The dissolution of the Biała Podlaska monastery was in line with the assumptions of Russian policy, leading to the liquidation of the Uniate Church and the extinction of the cult of Blessed Josaphat Kuncewicz, whose relics were in the Biala Podlaska church and were worshiped by both Roman and Greek Catholics. The liquidation of the Biała Podlaska monastery has permanently changed the religious and cultural scenery of the city and the surrounding area.

Key words: Basilian monks; Uniate Church; Basilian monastery in Biała Podlaska; the library of the Basilian monastery in Biała Podlaska; Josaphat Kuncewicz. 